\title{
Motives for Political Participation of the Physically Disabled People in Jordan
}

\author{
Aiman Awad Gharib \\ Al Balqa Applied University - Jordan \\ Email: Dr_aimanawad@yahoo.com \\ Hisham Ali Al Dmour \\ Dean of AL Karak College University, Al Balqa Applied University - Jordan \\ Email: Saifdhmour@yahoo.com
}

Accepted: November 17, 2012 Published: December 27, 2012

Doi:10.5296/jsr.v3i2.2796

URL: http://dx.doi.org/10.5296/jsr.v3i2.2796

\begin{abstract}
This study aimed to determine the motives for political participation among the physically disabled people in Jordan attributed the variables of age, experience, educational qualification and occupation.

The researcher used the descriptive method for the suitability of the study, and intentional sample was selected consisting of (9) players from "Nadi Al Mustaqbal for Motor Disability" in Amman. A questionnaire for motives was applied on them. After analyzing the data, we found that the order of the motives for political participation to the physically disabled in Jordan are: verbal and behavioral decency, followed by technical motives, then psychological motives, then social motives, then economic motives, and finally the profession motives. Also, we found that there were no statistically significant differences in the motives for political participation among the physically disabled people in Jordan attributed to the variables of age or experience. Yet for the variable of profession there were statistically significant differences in favor of staff in the field of verbal and behavioral decency. Furthermore, the results about the motives for political participation by the physically disabled people in Jordan were positive for all fields of study.
\end{abstract}

In light of the findings, the researcher recommended the need to provide search results to the Supreme Council for individuals with disabilities and Jordan Union of the disabled, as well as paying attention to the motivations of the physically disabled people in Jordan and working to develop them, as well as carrying out similar studies dealing with other groups of disabled people.

Keywords: Political participation, physically disabled people, motivation. 


\section{Introduction to the Study and Theoretical Framework}

Political Participation is of the important dimension to determine the political behavior of individuals; it is also one of the main axes in the area of interest of political science, social science and political psychology. studies and views agree to confirm the positive role of the individual in the political life through the right to nominate or vote in the elections, or showing interest in political issues and discussing them with others, or membership in organizations ...... etc. As it is an attempt to influence the decision makers, and participation is a voluntary and conscious affirmation of the right of the Democratic members of the community, and is an essential pillar of democracy, because it means people's exercise of their right to govern themselves (Rabea, 1999, p 17)

However there is almost a consensus among researchers on some versions of political participation that enable us to study and identify all the political, psychological, social and historical factors that contribute like voting in the elections, party affiliation, and membership of political organizations. these formulas of participation are associated with the mechanisms of the relationship between state and civil society practice and the nature of the prevailing political practice, and that institutionalizes the participation, which makes the essential role of the state is to encourage or discourage participation. (Qandil 0.1992 pp. 5-6)

The practice of the individual to the behavior of political participation - as a process earned depends on the availability of capacity and motivation of the individual, and the opportunities offered by community traditions and ideologies, as well as the conditions determined by the nature of the mainstream of political, social and economic climate in society. (Al Sayyed, 1994, p 16)

Hence, there is an importance for motivation and its role in the creation of the behavior of participation and its composition, as it provides the individual with incentives through which he receives the values of participation, and the more these values are, the more likely is the motivation of the individual's participation in the activities and different areas, with an increased depth of this participation (Aataran 1991 p 5).

The subject of the motives is one of the important topics in psychology, as it strengthens the relation with the process of cognition, memory, imagination, thinking and learning, and is the basis for the study of personal and mental health, due to the following fact that "all behavior are driven by motive" meaning that there are specific motivating force behind it. (Qashqoosh, 1979, p 31)

From the above we notes it's big mistakes made by political scientists to ignore the psychological dimension in analysis of political phenomenon, as it is inconceivable not to keep in mind this effective and efficient element in addressing the political phenomenon and, in this context "Lithman" referred in an article in the American Journal of Psychological 
to the weakness of the efforts of psychologists in the face of political phenomena in a single frame, saying: "I was frustrated for the handling of my colleagues in psychology of social to the various social and political phenomena, and it seems that we, the sons of psychology, cannot sometimes see the many complexities contained in such phenomena," He added in another part in his article, saying, "It seems that psychologists in dealing with these phenomena, especially if it includes multiple patterns, are not separated from the public in general in the treatment of such phenomena." (Ramzi: 1991, p 53).

For this, we find that the relationship between politics and psychology has increasingly been recognized, and the entrance in the psychological analysis of political phenomena has become an important matter and absolutely necessary if we are to understand these phenomena in the real right dimensions (Makki, 2005, p 33)

The psychological factors are important element for success in all areas of life, where (Qarqash, 2008, p 17) points that when there is a convergence of social, economic and cultural levels, the psychological factor is what determines the result of political participation. One of the important psychological factors in the progress and achievement is motivation, and therefore we can answer some important questions related to political participation, which relates to the exercise of physically disabled people of certain political activities, or refraining from that and what are the motives that stimulate the physically disabled to the exercise of political activities

As for the motivation of persons with disabilities for political participation in Jordan, we find that it had been, and still weak, due to the situation of the disabled in Jordan who are marginalized and excluded from the scene of official political participation, although the legal status of political participation in Jordan is clear to us through what is stipulated by the Constitution of Jordan in the chapter dealing with the rights and Duties of Jordanians that "the State shall guarantee freedom of opinion, and every Jordanian has the right to express his opinion freely in speech, writing, photography and other means of expression, provided that he does not exceed the limits of the law. In addition, Jordanians are entitled to form associations and political parties provided that they are legitimate, lawful and do not violate the Constitution. Item (a) of Article (3) of the Election Law states that "Every Jordanian completed nineteen solar years of age on July 31 of each year as the right to elect members of the House of Representative if his name was registered in one of the final voter tables," and Article (18) of the Act identified the conditions of candidacy for membership of the House of Representatives and the terms of article (19) permit any person to stand for membership of the Council in one electoral district. (The Constitution of Jordan, 2011)

Based on the foregoing, it can be said that the Jordanian Constitution of 1952 and the laws regulating the political action as law of parties and election law, secured the right of political participation, for those related to freedom of opinion, speech, writing, or photography, and other means of expression, or with regard to the establishment of political parties and the nomination and voting in parliamentary or municipal elections and other activities of the 
political participation for all citizens, regardless of whether the person is disabled or not. (The Constitution of Jordan, 1952)

In this context, Navi Pele, (2012) called the High Commissioner for Human Rights to remove barriers that hinder the participation of persons with disabilities in political and public affairs. She said in front of the Human Rights Council in Geneva, "The ratification of the UN Convention on the Rights of Persons with Disabilities is not sufficient in itself to ensure that they enjoy all their rights in all areas." Noting that the article "29" in the treaty requires States to take appropriate steps to strengthen the provision of an appropriate environment in which persons with disabilities can participate effectively and fully in the conduct of public affairs without discrimination and on an equal basis with others. These steps include removing all legal and physical barriers that prevent people with disabilities from exercising their right to participate in political and public life in their countries. (Council of Human Rights, 2012)

Human rights experts called for work in order to ensure the participation of persons with disabilities in the political life through the introduction of legal reforms and change the prevailing thought about them and consider them as equal citizens able to make their own decisions.

Experts said that the right of political participation is located in the heart of democracy and means to participate in decision-making and in the field of public issues, which is real citizenship and equality, and ensuring the right of equal political participation to persons with disabilities requires not only legal reform in many countries around the world, but also doing more challenging things, as the treaty requires everyone to change the way of thinking about people with disabilities and to consider them as equal citizens who deserve the dignity and independence in their decision making. (Human Rights Council, 2011)

Despite the adoption of the International Convention for the Rights of Persons with Disabilities in the year (2006) and the ratification by one hundred and nine countries so far, yet a recent study conducted by the Office of the High Commissioner for Human Rights has shown that people with disabilities continue to face obstacles and challenges in various areas in many countries of the world. (Human Rights Council, 2011).

\section{Terms of Study}

Motivation: the case of internal physical or psychological drive toward individual behavior in certain circumstances and its orientation towards satisfying a need or a specific target that is a driving force booster and targeted at the same time. (Nashawati, 1996, p 37)

Political Participation: is the process by which the individual plays role in the political and community, and has a chance to contribute in the setting of the overall objectives of the community, and determining the best means to accomplish them through the direct or indirect activities. (Al Baz, 2003, p 358) 
Motor impairment: A disability that hinders the individual from the movement because of a defect, deformity or disease that happened to the muscles or joints in a way that limits normal jobs, or the loss of one of the body parts which affect the education of the disabled and his support for himself, as well as the personal and social adaptation. (Qaryouti, 2000, p 52)

\section{Previous Studies}

- the researcher Did not find any study on the level of Jordan or the Arab world on the subject of motives of the physically disabled to exercise politically, but he found one study in the U.S. related to the subject conducted by Shleder and others (1998), which examined the individual electoral factors and their impact on the political participation of people with disabilities in year (1984) and year (1986) based on data collected in the years mentioned. It showed that political activity for the disabled depends on demographic and psychological factors, as well as on the behavior of candidates and the government's performance towards the disabled. This indicates that the political participation of people with disabilities depends to a large extent on the political elites to address the concerns of Political candidates themselves in the future.

Never the less, on the subject of political participation, there are many similar studies shown as follows:

Arman (2010) Conducted a study that aimed to identify the factors affecting the political participation of the Jordanian society in general and the community of Northern Badia in particular, through the identification of the impact of personal variables and factors such as age, sex, educational level, and economic variables such as the nature of profession and income level, and cultural variables on the nature and level of political participation. the study population consisted of all the villages consisting North Badia, which includes three areas the Northwest Badia, which has a population of $(80,500)$, the north-east Badia of a population of $(61,470)$, and Ruweished with a population that reached $(7,460)$ people The sample consisted of (700) individual, and to reach the results of the study, the researcher used the questionnaire. The study showed that the most important variables that affected the pattern and level of political participation to members of the sample are tribal culture, age, academic level, while showing the existence of differences for each of the variables of level of income, the profession, and the number of family members. The study did not show any statistically significant differences at the level of statistical significance for the variable of sex, and marital status.

Al Sharaa (2008) study aimed to identify the trends of the rural population of Jordan towards political participation and know the effect of personal, social, economic, political variables on political participation. The study population consisted of all members of the tribe of (Bani Obeid) aged between (18) years and above. The results of the study showed that there are 
some differences between the educational levels at the sample and its attitude towards participation, and the variable of marital status did not show any effect on the attitudes of the sample about patterns of participation. Also, the study showed there were some statistical differences between the attitudes of males and females to participate, and the results indicated that he most important variables that influenced the political participation were the variable of sex, education, family size, income, but the study did not show any statistically significant differences for the variables of age, marital status, profession on political participation of members of the sample.

Also, Haddad (2006) conducted a comparative psychological study between samples of the Palestinian participants and non-participating politically. The study sample consisted of (488) forming three sub-samples (University students, university professors, security officers) the study came with a number of results including: distinguishing political participants from non-political participants in terms of satisfaction, and that there are no differences between male and female political participation.

Al Miqdad (2004) study aimed to shed light on the reality of participation of Jordanian women in public life by diagnosing their activity in established organizations and associations on the one hand, and experience in political participation in the legislative assemblies on the other hand. The results showed that social, cultural and media factors are still rooted and that the ratios of expression in the granting of the votes remain constant. also the responsibility lies on women themselves, as they still do not elect their sex, so they should take advantage of seats granted by a government through the modified election system "quota system", and the seats they reached through appointments, and thus recommending to maintain the modified system in mind for the next electoral cycle, in order to help change the community perception of women contribution, through its presence in different positions.

In a study for Al Naqshbandi (2000) to identify the political participation of women in Jordan and some Arab countries, aimed to address the factors that have affected the situation of Arab women and their political participation in general, and those factors affecting the status of Jordanian women in particular. the sample consisted of (70) woman selected randomly, and to reach the results of the study, the researcher used the method of field research to assess the political participation of Jordanian women, where the study relied on interviews with women activists in Jordan who were interviewed about their opinions on important and influential issues on women's political participation, like affiliation to political parties as well as to assess the role of women's organizations in Jordan. The respondents positions were divided into two parts: the first sees that women's organizations have a positive role in promoting women's political participation, and the second believes that these organizations do not their roles efficiently in political participation of women.

As for Hamza (1995), in the study entitled: "The psychology of political participation - a comparative psychological study comparison between participants and non participants politically. The study aimed to know whether there are significant differences between 
participants politically and non-participants in political alienation attitude towards power and religious orientation and some personal properties. The study found that participants politically are less alienated and more politically submissive to authority and they have a high religious orientation, they are more satisfied and less nervous, and more willing to lies with higher level in the economic and social levels more than the non-participants...

Al Azzam (1991) study aimed to identify trends in a selected sample of Jordanian society towards political participation, and discussed the relationship of some personal, economic and social variables, such as race, age, education level, place of residence, income, occupation, family size on political participation. The study population consisted of (South, Central and North Kingdom of Jordan), and the results showed that there is a close relationship between the personal, social, and economic variables with political participation, where it confirmed the existence of statistically significant differences between the variables of education level, income, family size and political participation, while it did not confirm the existence of statistically significant differences attributed to the variable of gender effecting political participation.

\section{Comment on Previous Studies}

Through review of the previously mentioned Studies in the field of political participation: the researched came up with a set of hypotheses:

1. The Motive for political participation of the physically disabled people in Jordan is: Decency of speech and behavior motives, social motives, psychological motives, economic motives, technical motives, and profession motives.

2. There are no statistically significant differences at the level of (œ $\geq 0.05$ ) in the various motives for the following variables: age levels, levels of experience, levels of academic qualification, and levels of profession.

The current study shares with previous studies in the same variables, but differs in the society and study sample. What is unique in the study is handling the motivation of the physically disabled to participate politically.

\section{Problem of the Study}

The Jordanian society has witnessed accelerated social and economic developments during the past four decades, that the programs of social and economic development contributed in improving both the education and health of citizens, and through these programs the disabled achieved great achievements in the areas of education, and sports, but in spite of these achievements their political participation is still very low.

It is certain that the involvement of disabled people in the political life of Jordan helps to integrate them in the development process on the comprehensive scope, and it is worth mentioning that the issue of political participation for the disabled is not a subject isolated or 
separate from the issues of the Jordanian society, since the experience of political participation in Jordan, is one of the experiences of Arab growing countries that lack maturity and stability. Therefore, promoting the participation of disabled people is primarily linked to the political development in the community as a whole and to achieving political reform in it. (Al- Hazaima, 2005)

In view of this, the researcher believes that barriers to political participation for the disabled can be summarized as follows: -

1 - the social construction of Jordan is a traditional one characterized by the dominance of parents with the support of social, family, religious, economic, educational and political institutions that reinforce the traditional roles of social roles, that is; in spite of the changes in the functions of the conventional units (such as family and tribe), still these units play a central role in resolving many of the manifestations of political participation for the benefit of normal healthy people, marginalizing the role of the disabled, as the handicapped lack financial and moral support in their election campaigns and lack support from informal political leaders, and have limited movement within the community.

2 - Prevailing Jordanian culture is a traditional culture, based on the value system, customs and traditions that force a stereotype of the disabled through socialization, and cultural beliefs determine what appropriate and inappropriate roles are for the normal healthy people and the disabled.

3 - There is no stability and maturity of political participation in the Jordanian society in general, and the disabled lack the experience in political action in particular, that's why the disabled have been excluded for decades from political participation in the country.

4 - Weakness of civil society institutions in Jordan, which affects their role in activating and promoting the political participation of citizens, whether normal healthy or disabled, as modern units that can be alternative units for conventional ones.

\section{Importance Of The Study}

This study importance emerges from looking at the motives of the political participation of the physically disabled in Jordan for a number of requirements which are:

a- $\quad$ The Need to provide the requirements and basic needs of the disabled in general and the physically disabled, in particular, that meet the physical and psychological gratification, and allows them a degree of willingness to participate in public life within the home.

b- High level of awareness of the physically disabled, in the political, economic and social dimensions of the conditions the society is going through 


\section{Al Macrothink}

Journal of Sociological Research

ISSN 1948-5468

2012, Vol. 3, No. 2

c- $\quad$ Sense of belonging to the homeland, and a sense of the disabled that their participation in the political, social and economic development of society is a duty imposed by belonging to this homeland.

d- Sense of the physically disabled in the importance and the effectiveness of their participation and the speed of response from officials, and this deepen the sense of the usefulness of this participation, and benefit directly to improve the image of their life within the community.

e- Belief by many political leadership and conviction of the importance of participation of disabled people in making and implementing public policies, and providing them the opportunity to support this by ensuring the participation of political freedom, allowing them to express their hopes, ambitions, and their opinion in the issues of their society and its problems.

f- The existence of legislation to ensure and protect the participation, as well as various means and methods, to introduce and discuss views, ideas and proposals clearly and with complete freedom.

\section{Objectives Of The Study}

The aim of this study is to identify:

1. Motives of political participation among physically disabled in Jordan.

2. Motives of political participation among physically disabled in Jordan according to the variable of age.

3. Motives of political participation among physically disabled in Jordan variable according to the variable of experience.

4. Motives of political participation among physically disabled in Jordan variable according to academic qualifications.

5. Motives of political participation among physically disabled in Jordan according to the variable of profession.

\section{The Study Questions}

This study raised the following questions:

1 - What are the motives of political participation for the physically disabled in Jordan?

2 - Are there significant differences at the level of ( $\geq 0.05)$ between the levels of physically disabled motives for political participation in Jordan attributed to the variable of age?

3 - Are there significant differences at the level of ( $\propto 20.05)$ between the levels of physically disabled motives for political participation in Jordan attributed to the variable of experience?

4 - Are there significant differences at the level of ( $\geq 0.05)$ between the levels of physically disabled motives for political participation in Jordan attributed to the variable of educational qualification?

5 - Are there significant differences at the level of ( $\geq 0.05$ ) between the levels of physically disabled motives for political participation in Jordan attributed to the variable of the 
profession?

\section{Research Methodology And Field Procedures}

The study population: it consisted of the total of all the physically disabled and officially registered people in the records of "Nadi Al Mustaqbal" for physical disability, and the Jordanian Union for sports of the disabled in the capital Amman. The number of registered disabled people according to the records of this club are (137) players.

The study sample: a questionnaires was distributed to the study sample, consisting of (9) people disabled physically out of (14) who had the motives and tendencies to participate in the parliamentary elections, but (5) questionnaires were excluded for non-compliance with conditions, and this sample has represented $64.28 \%$ of the initial study sample, and table (1) shows the characterization of the sample.

Table (1) showing frequencies and percentages for the members of the study sample distributed according to the independent variables.

\begin{tabular}{|l|l|l|l|}
\hline Variable & Category & Count & Percentage \\
\hline \multirow{4}{*}{ Age } & Less than 20 Years & 5 & $\mathbf{5 5 . 5 6 \%}$ \\
\cline { 2 - 4 } & More than 20 years & 4 & $\mathbf{4 4 . 4 4 \%}$ \\
\cline { 2 - 4 } & Total & $\mathbf{9}$ & $\mathbf{1 0 0 \%}$ \\
\hline \multirow{4}{*}{ Experience } & 10 years or less & 5 & $\mathbf{5 5 . 5 6 \%}$ \\
\cline { 2 - 4 } & More than 10 years & 4 & $\mathbf{4 4 . 4 4 \%}$ \\
\cline { 2 - 4 } & Total & $\mathbf{9}$ & $\mathbf{1 0 0 \%}$ \\
\hline \multirow{3}{*}{$\begin{array}{l}\text { Quadification } \\
\text { Profession }\end{array}$} & Secondary (High School)or less & $\mathbf{8}$ & $\mathbf{8 8 . 8 9 \%}$ \\
\cline { 2 - 4 } & University Graduate & $\mathbf{1}$ & $\mathbf{1 1 . 1 1 \%}$ \\
\cline { 2 - 4 } & Total & $\mathbf{9}$ & $\mathbf{1 0 0 \%}$ \\
\cline { 2 - 4 } & Student & $\mathbf{3}$ & $\mathbf{3 3 . 3 3 \%}$ \\
\cline { 2 - 4 } & Employee & $\mathbf{6}$ & $\mathbf{6 6 . 6 7 \%}$ \\
\cline { 2 - 4 } & Total & $\mathbf{9}$ & $\mathbf{1 0 0 \%}$ \\
\hline
\end{tabular}

\section{Methodology Of The Study}

The Researcher used the Survey descriptive method, and this is the most appropriate approach to the subject of the study.

\section{Data Collection Tool}

The researcher designed a tool for the study which was a questionnaire used to collect the 
necessary data from the study sample. This questionnaire was evaluated by many professionals, and it achieved high validity and reliability. It consisted from (6) areas and (38) items, through which we can answer questions of the study and thus achieve their goals.

\section{Transaction Validity and Reliability Coefficient Of The Tool}

Validity: The content validity of the study tool (scale, motivated,) was reached via consulting a panel of judges consisted of (10) university experts who have competence and experience. They unanimously agreed to the validity of a rate (75\%). See Supplement No. (2).

Reliability: it has been verified (scale, motivated, ...) using the method of (Test-Re-Test Reliability) on the exploratory sample (standardized sample), which amounted to (10) of the physically disabled in the Jordanian Union of Sports for the disabled, then they were excluded from the study sample and then re-test on the same group took place after two weeks (to exclude the factor to remembering). Pearson correlation coefficient was calculated, where the degree of correlation between the first application and the second was (0.88), a value that is relatively high.

\section{Showing The Results}

The researcher presented the results of the study, after applying the tools of the study, data collection and analysis, where the study tried to investigate motivation for political participation for people with physically disabilities based on the motives: verbal and behavioral decency, social, psychological, economic, technical, and profession ones. The following is a presentation of the results of testing hypotheses of the study:

Table (2) shows the mean, standard deviation and relative importance of each item of the field of verbal and behavioral decency $(n=9)]$

\begin{tabular}{|l|l|l|l|l|l|}
\hline Field & Mean & $\begin{array}{l}\text { Standard } \\
\text { Deviation }\end{array}$ & $\begin{array}{l}\text { Relative } \\
\text { Importanc } \\
\text { e }\end{array}$ & $\begin{array}{l}\text { Field } \\
\text { Order }\end{array}$ & $\begin{array}{l}\text { Place in the } \\
\text { Questionnaire }\end{array}$ \\
\hline $\begin{array}{l}\text { To keep my verbal } \\
\text { behavioral decency }\end{array}$ & 5 & 0 & 100 & 1 & 1 \\
\hline $\begin{array}{l}\text { To improve my job } \\
\text { efficiency }\end{array}$ & 4.89 & 0.33 & 97.8 & 2 & 8 \\
\hline $\begin{array}{l}\text { Because it gives me } \\
\text { freedom of movement }\end{array}$ & 5 & 0 & 100 & 1 & 2 \\
\hline $\begin{array}{l}\text { Because it helps me } \\
\text { socialize }\end{array}$ & 1.8 & 60 & 5 & 26 \\
\hline
\end{tabular}




\begin{tabular}{|l|l|l|l|l|l|}
\hline $\begin{array}{l}\text { To keep my personality } \\
\text { stable and fair }\end{array}$ & 4.33 & 1.12 & 86.6 & 4 & 15 \\
\hline $\begin{array}{l}\text { To improve my personal } \\
\text { skills }\end{array}$ & 4.44 & 1.33 & 88.8 & 3 & 13 \\
\hline $\begin{array}{l}\text { Because it suits my } \\
\text { personal abilities }\end{array}$ & 5 & 0 & 100 & 1 & 3 \\
\hline Total & 4.52 & 0.34 & 90.4 & & \\
\hline
\end{tabular}

By review the values shown in the table, we find that the first item "to maintain verbal and behavioral decency ", the third, "because it offers me the freedom of movement," and seven "because it is consistent with my personal abilities "have occupied first place among the items of the field with a mean of $(5.0 \pm 0)$ and the relative importance of $100.0 \%$, while the fourth item, which states," because they contribute to my socialization " was ranked last with mean of $(3.0 \pm 1.8)$ and the relative importance of $(60.0 \%)$. The mean of the area as a whole amounted to $(4.52 \pm 0.34)$ and the relative importance of $(90.40 \%)$.

Table (3) shows the arithmetic mean, standard deviation and relative importance of each item of the field of social motivation $(n=9)$

\begin{tabular}{|l|l|l|l|l|l|}
\hline Field & Mean & $\begin{array}{l}\text { Standard } \\
\text { Deviation }\end{array}$ & $\begin{array}{l}\text { Relative } \\
\text { Importance }\end{array}$ & $\begin{array}{l}\text { Field } \\
\text { Orde } \\
\text { r }\end{array}$ & $\begin{array}{l}\text { Place in the } \\
\text { Questionnaire }\end{array}$ \\
\hline $\begin{array}{l}\text { Because it popularize } \\
\text { me locally }\end{array}$ & 1.67 & 1 & 33.4 & 5 & 32 \\
\hline $\begin{array}{l}\text { Because I find } \\
\text { encouragement from } \\
\text { my friends }\end{array}$ & 1.22 & 0.44 & 24.4 & 6 & 38 \\
\hline $\begin{array}{l}\text { To increase the } \\
\text { number of my friends } \\
\text { and acquaintances }\end{array}$ & 4.33 & 0.71 & 86.6 & 2 & 16 \\
\hline $\begin{array}{l}\text { Because My parents } \\
\text { and relatives } \\
\text { encourage me }\end{array}$ & 5 & 0 & 100 & 1 & 4 \\
\hline $\begin{array}{l}\text { Because it is the most } \\
\text { common participation } \\
\text { in my country improve my }\end{array}$ & 1.89 & 1.17 & 37.8 & 4 & 30 \\
\hline $\begin{array}{l}\text { To ind social } \\
\text { financial and } \\
\text { status and }\end{array}$ & 4.22 & 0.67 & 84.4 & 3 & 19 \\
\hline $\begin{array}{l}\text { Because it creates } \\
\text { social values and }\end{array}$ & 23.56 & 7 & 39 \\
\hline
\end{tabular}




\begin{tabular}{|l|l|l|l|l|l|}
\hline habits & & & & & \\
\hline Total & $\mathbf{3 . 0 6}$ & $\mathbf{0 . 3 9}$ & $\mathbf{6 1 . 2}$ & & \\
\hline
\end{tabular}

by review of the values contained in the table, we find that the fourth item, which states that "because I found encouragement from my family and relatives" was ranked first among items with a mean of $(5.0 \pm 0)$ and the relative importance $(100.0 \%)$, while the sixth item, had the last rank as it says: "to improve my financial status" with a mean of $(1.19 \pm 0.31)$ and the relative importance of $23.56 \%$. As for the mean of the area as a whole it was (3.06 \pm 0.39$)$ and the relative importance was $61.20 \%$,

Table (4) shows the mean, standard deviation and relative importance of each item of the field of psychological motivation $(n=9)$

\begin{tabular}{|l|l|l|l|l|l|}
\hline Field & Mean & $\begin{array}{l}\text { Standard } \\
\text { Deviation }\end{array}$ & $\begin{array}{l}\text { Relative } \\
\text { Importance }\end{array}$ & $\begin{array}{l}\text { Field } \\
\text { Orde } \\
\text { r }\end{array}$ & $\begin{array}{l}\text { Place in the } \\
\text { Questionnaire }\end{array}$ \\
\hline $\begin{array}{l}\text { Because it makes me } \\
\text { rely on myself }\end{array}$ & 5 & 0 & 100 & 1 & 5 \\
\hline $\begin{array}{l}\text { To have an impressive } \\
\text { personality }\end{array}$ & 4.33 & 1.41 & 86.6 & 4 & 17 \\
\hline $\begin{array}{l}\text { Because it releases my } \\
\text { tension and stress }\end{array}$ & 3.89 & 1.36 & 77.8 & 6 & 22 \\
\hline $\begin{array}{l}\text { Because it makes me } \\
\text { feel satisfied }\end{array}$ & 4.22 & 1.39 & 84.4 & 5 & 20 \\
\hline $\begin{array}{l}\text { To acquire good } \\
\text { manners like courage }\end{array}$ & 4.44 & 1.33 & 88.8 & 3 & 14 \\
\hline $\begin{array}{l}\text { To gain respect from } \\
\text { others }\end{array}$ & 4.89 & 0.33 & 97.8 & 2 & 9 \\
\hline $\begin{array}{l}\text { Because it dispatches } \\
\text { me from daily problems }\end{array}$ & 2.3 & 2 & 46.6 & 7 & 28 \\
\hline Total & 4.16 & 0.95 & 83.2 & & \\
\hline
\end{tabular}

by review of the values shown in the table we find that the first item which states "because it makes me rely on myself," was ranks first among the items of the field with a mean of $(5.0 \pm$ 0 ) and the relative importance of $100.0 \%$, while the seventh item, which states "because it dispatches me from the problems of daily life" was ranked last with a mean of $(2.33 \pm 2.0)$ and the relative importance of $46.60 \%$. As for the mean of the field as a whole it was $(4.16 \pm$ $0.95)$ and the relative importance of $83.20 \%$.

Table (5) shows the mean, standard deviation and relative importance of each item of the field of economic motives $(n=9)$ 


\begin{tabular}{|l|l|l|l|l|l|}
\hline Field Mean & $\begin{array}{l}\text { Standard } \\
\text { Deviation }\end{array}$ & $\begin{array}{l}\text { Relative } \\
\text { Importan } \\
\text { ce }\end{array}$ & $\begin{array}{l}\text { Field } \\
\text { Orde } \\
\text { r }\end{array}$ & $\begin{array}{l}\text { Place in the } \\
\text { Questionnai } \\
\text { re }\end{array}$ \\
\hline $\begin{array}{l}\text { Because it earns me } \\
\text { money }\end{array}$ & 1.44 & 0.73 & 28.8 & 4 & 35 \\
\hline $\begin{array}{l}\text { To gain moral and } \\
\text { material motives the }\end{array}$ & 1.56 & 0.73 & 31.2 & 3 & 33 \\
\hline $\begin{array}{l}\text { Because for } \\
\text { requirements } \\
\text { political participation are } \\
\text { available }\end{array}$ & 1.01 & 31.2 & 3 & 34 \\
\hline $\begin{array}{l}\text { For the many privileges } \\
\text { granted to politicians }\end{array}$ & 1.89 & 1.17 & 37.8 & 2 & 31 \\
\hline $\begin{array}{l}\text { Because it gives me the } \\
\text { chance to travel abroad }\end{array}$ & 4.89 & 0.33 & 97.8 & 1 & 10 \\
\hline $\begin{array}{l}\text { Because it is materially } \\
\text { inexpensive }\end{array}$ & 4.89 & 0.33 & 97.8 & 1 & 11 \\
\hline Total & 2.7 & 0.61 & 54 & & \\
\hline
\end{tabular}

By review of the values shown in the table, we find that the fifth item "because it gives me the chance of travel abroad for free," and the sixth "because it is inexpensive materially" are ranked first among the items with a mean of $(4.89 \pm 0.33)$ and the relative importance of (97.80\%), while the first item which states "because they earn me money" was ranked last with the mean of $(1.44 \pm 0.73)$ and the relative importance of $(28.80 \%)$. As for the mean of the field as a whole it amounted to $(2.7 \pm 0.61)$ and the relative importance of $(54.0 \%)$

Table (6) shows the mean, standard deviation and relative importance of each item of the field of technical motivation $(n=9)$

\begin{tabular}{|l|l|l|l|l|l|}
\hline Field & Mean & $\begin{array}{l}\text { Standar } \\
\text { d } \\
\text { Deviatio } \\
\text { n }\end{array}$ & $\begin{array}{l}\text { Relative } \\
\text { Importance }\end{array}$ & $\begin{array}{l}\text { Field } \\
\text { Orde } \\
\text { r }\end{array}$ & $\begin{array}{l}\text { Place in the } \\
\text { Questionnair } \\
\text { e }\end{array}$ \\
\hline $\begin{array}{l}\text { To reach political } \\
\text { distinctiveness and } \\
\text { excellence }\end{array}$ & 4.56 & 1.33 & 91.2 & 2 & 12 \\
\hline $\begin{array}{l}\text { To raise the name of my } \\
\text { country high in political } \\
\text { forums }\end{array}$ & 5 & 0 & 100 & 1 & 6 \\
\hline $\begin{array}{l}\text { to interact with my } \\
\text { counterparts politicians } \\
\text { abroad }\end{array}$ & 5 & 0 & 100 & 1 & 7 \\
\hline
\end{tabular}




\begin{tabular}{|l|l|l|l|l|l|}
\hline $\begin{array}{l}\text { To master the skills of } \\
\text { the political "game" }\end{array}$ & 4.33 & 0.87 & 86.6 & 3 & 18 \\
\hline $\begin{array}{l}\text { Due to my knowledge in } \\
\text { the diplomatic rules }\end{array}$ & 4 & 1.32 & 80 & 4 & 21 \\
\hline $\begin{array}{l}\text { Because it aims to satisfy } \\
\text { my self-concept }\end{array}$ & 3.33 & 1.32 & 66.6 & 5 & 24 \\
\hline Total & 4.37 & 0.43 & 87.4 & & \\
\hline
\end{tabular}

By review of the values shown in the table, we find that the second item "to raise the name of my country high in the political forums," and the third "to interact with my counterparts politicians abroad " were ranked the first with a mean $(5.0 \pm 0)$ and the relative importance of (100.0\%), while the sixth item, which states "because it aims to satisfy my self-concept " was ranked last with an average account valued at $(3.33 \pm 1.32)$ and the relative importance was (66.60\%). As for the means of the field as a whole it amounted to $(4.37 \pm 0.43)$ and the relative importance of $(87.40 \%)$.

Table (7) the show the mean, standard deviation and relative importance of each item of the field of profession motives $(n=9)$

\begin{tabular}{|l|l|l|l|l|l|}
\hline Field & Mean & $\begin{array}{l}\text { Standard } \\
\text { Deviation }\end{array}$ & $\begin{array}{l}\text { Relative } \\
\text { Importance }\end{array}$ & $\begin{array}{l}\text { Field } \\
\text { Orde } \\
\text { r }\end{array}$ & $\begin{array}{l}\text { Place in the } \\
\text { Questionnaire }\end{array}$ \\
\hline $\begin{array}{l}\text { Because I want to be } \\
\text { an eminent politician } \\
\text { in the future }\end{array}$ & 3.22 & 1.86 & 64.4 & 2 & 25 \\
\hline $\begin{array}{l}\text { Because it offers me a } \\
\text { job }\end{array}$ & 2.11 & 1.76 & 42.2 & 4 & 29 \\
\hline $\begin{array}{l}\text { Institutions in my } \\
\text { country are interested } \\
\text { in the political person }\end{array}$ & 1.33 & 0.71 & 26.6 & 6 & 37 \\
\hline $\begin{array}{l}\text { because it qualifies me } \\
\text { to become a minister } \\
\text { in the future }\end{array}$ & 3.89 & 1.69 & 77.8 & 1 & 23 \\
\hline $\begin{array}{l}\text { To be able to perform } \\
\text { my job well }\end{array}$ & 2.78 & 1.79 & 55.6 & 3 & 27 \\
\hline $\begin{array}{l}\text { To get the satisfaction } \\
\text { of my boss at work }\end{array}$ & 1.44 & 1.33 & 28.8 & 5 & 36 \\
\hline Total & 2.46 & 1.15 & 49.2 & & \\
\hline
\end{tabular}

By review the values shown in the table, we find that the fourth item "because it qualifies me to become a minister in the future" was ranked first with a mean of $(3.89 \pm 1.69)$ and the relative importance of $(77.80 \%)$, while the third item, which states that "institutions in my 
country are interested in political person" was ranked last with a mean that reached $(1.33 \pm$ $0.71)$ and the relative importance of $(26.60 \%)$. As for the mean of the field as a whole it amounted to $(2.46 \pm 1.15)$ and the relative importance of $(49.2 \%)$,

Table (8) shows the mean, standard deviation and the relative importance of each area of study $(\mathbf{n}=9)$

\begin{tabular}{|l|l|l|l|l|}
\hline Field & Mean & $\begin{array}{l}\text { Standard } \\
\text { Deviation }\end{array}$ & $\begin{array}{l}\text { Relative } \\
\text { Importance }\end{array}$ & $\begin{array}{l}\text { The } \\
\text { Order }\end{array}$ \\
\hline Verbal and behavioral decency motives & 4.52 & 0.34 & 90.4 & 1 \\
\hline Social motives & 3.06 & 0.39 & 61.2 & 4 \\
\hline Psychological motives & 4.16 & 0.95 & 83.2 & 3 \\
\hline Economical motives & 2.7 & 0.61 & 54.0 & 5 \\
\hline Technical motives & 4.37 & 0.43 & 87.4 & 2 \\
\hline Profession motives & 2.46 & 1.15 & 49.2 & 6 \\
\hline Total & 3.55 & 0.3 & 71.0 & \\
\hline
\end{tabular}

By review of the values shown in the table, we find that the motives of "behavioral and verbal decency" was ranked first with a mean of $(4.52 \pm 0.34)$ and the relative importance of $90.40 \%$, while the profession motives ranked last with a mean that reached $(2.46 \pm 1.15)$ and the relative importance of $49.20 \%$. As for the mean of the areas as a whole it amounted to $(3.55 \pm 0.3)$ and the relative importance of $71 \%$.

Table (9) shows the mean, standard deviation and the value of calculated (t) for the fields of study depending on the variable age

\begin{tabular}{|c|c|c|c|c|c|c|}
\hline Field & Age & Mean & $\begin{array}{l}\text { Standar } \\
\text { d } \\
\text { Deviatio } \\
\text { n }\end{array}$ & $\begin{array}{l}\text { Means } \\
\text { differenc } \\
\text { e }\end{array}$ & $\begin{array}{l}\text { Calculate } \\
\text { d } \quad(t) \\
\text { Value }\end{array}$ & $\begin{array}{l}\text { Sig. } \\
\text { Leve } \\
1\end{array}$ \\
\hline \multirow{2}{*}{$\begin{array}{l}\text { Verbal and } \\
\text { behavioral } \\
\text { decency motives }\end{array}$} & 25 years or less & 4.71 & 0.34 & \multirow[t]{2}{*}{0.42} & \multirow[t]{2}{*}{2.41} & \multirow{2}{*}{$\begin{array}{l}0.04 \\
6\end{array}$} \\
\hline & $\begin{array}{l}\text { More than } 25 \\
\text { years }\end{array}$ & 4.29 & 0.12 & & & \\
\hline \multirow[t]{2}{*}{ Social motives } & 25 years or less & 3.03 & 0.52 & \multirow[t]{2}{*}{0.5} & \multirow[t]{2}{*}{0.17} & \multirow{2}{*}{$\begin{array}{l}0.86 \\
3\end{array}$} \\
\hline & $\begin{array}{l}\text { More than } 25 \\
\text { years }\end{array}$ & 30.8 & 0.22 & & & \\
\hline \multirow{2}{*}{$\begin{array}{l}\text { Psychological } \\
\text { motives }\end{array}$} & 25 years or less & 4.69 & 0.38 & \multirow[t]{2}{*}{1.64} & \multirow[t]{2}{*}{2.30} & \multirow{2}{*}{$\begin{array}{l}0.05 \\
5\end{array}$} \\
\hline & $\begin{array}{l}\text { More than } 25 \\
\text { years }\end{array}$ & 3.5 & 1.08 & & & \\
\hline \multirow{2}{*}{$\begin{array}{l}\text { Economical } \\
\text { motives }\end{array}$} & 25 years or less & 2.73 & 0.80 & \multirow[t]{2}{*}{0.06} & \multirow[t]{2}{*}{0.15} & \multirow{2}{*}{$\begin{array}{l}0.88 \\
3\end{array}$} \\
\hline & $\begin{array}{l}\text { More than } 25 \\
\text { years }\end{array}$ & 2.67 & 0.38 & & & \\
\hline
\end{tabular}




\begin{tabular}{|c|c|c|c|c|c|c|}
\hline \multirow[t]{2}{*}{ Technical motives } & 25 years or less & 4.17 & 0.44 & \multirow[t]{2}{*}{0.46} & \multirow[t]{2}{*}{1.78} & \multirow{2}{*}{$\begin{array}{l}0.11 \\
7\end{array}$} \\
\hline & $\begin{array}{l}\text { More than } 25 \\
\text { years }\end{array}$ & 4.63 & 0.28 & & & \\
\hline \multirow[t]{2}{*}{ Profession motives } & 25 years or less & 1.67 & 0.53 & \multirow[t]{2}{*}{1.79} & \multirow[t]{2}{*}{3.79} & \multirow{2}{*}{$\begin{array}{l}\mathbf{0 . 0 0} \\
7\end{array}$} \\
\hline & $\begin{array}{l}\text { More than } 25 \\
\text { years }\end{array}$ & 3.46 & 0.89 & & & \\
\hline \multirow[t]{2}{*}{ Total } & 25 years or less & 3.5 & 0.31 & \multirow[t]{2}{*}{0.10} & \multirow[t]{2}{*}{0.48} & \multirow{2}{*}{$\begin{array}{l}0.64 \\
5\end{array}$} \\
\hline & $\begin{array}{l}\text { More than } 25 \\
\text { years }\end{array}$ & 3.6 & 0.33 & & & \\
\hline
\end{tabular}

By review of the values of calculated (v), we find that it is not statistically significant because the level of significance was between (0.15 - 3.79), which is higher than (0.05) in all the values of the calculated $(\mathrm{t})$ in all the fields and all the sections of the variable of age (25 years old and under / over 25 years).

Table (10) shows the mean, standard deviation and the value of calculated (t) for fields of study depending on the experience variable (Training Period)

\begin{tabular}{|c|c|c|c|c|c|c|}
\hline Field & $\begin{array}{l}\text { Training } \\
\text { Period }\end{array}$ & Mean & $\begin{array}{l}\text { Standard } \\
\text { Deviation }\end{array}$ & $\begin{array}{l}\text { Means } \\
\text { difference }\end{array}$ & $\begin{array}{l}\text { Calculated } \\
\text { (t) Value }\end{array}$ & $\begin{array}{l}\text { Sig. } \\
\text { Level }\end{array}$ \\
\hline \multirow{2}{*}{$\begin{array}{l}\text { Verbal and } \\
\text { behavioral decency } \\
\text { motives }\end{array}$} & $\begin{array}{l}\text { Less than } 10 \\
\text { years }\end{array}$ & 4.71 & 0.43 & \multirow[t]{2}{*}{0.42} & \multirow[t]{2}{*}{2.41} & \multirow[t]{2}{*}{0.046} \\
\hline & $\begin{array}{l}\text { More than } 10 \\
\text { years }\end{array}$ & 4.29 & 0.12 & & & \\
\hline \multirow[t]{2}{*}{ Social motives } & $\begin{array}{l}\text { Less than } 10 \\
\text { years }\end{array}$ & $\mathbf{3 . 0 3}$ & 0.52 & \multirow[t]{2}{*}{0.5} & \multirow[t]{2}{*}{0.17} & \multirow[t]{2}{*}{0.863} \\
\hline & $\begin{array}{l}\text { More than } 10 \\
\text { years }\end{array}$ & 3.08 & 0.22 & & & \\
\hline \multirow[t]{2}{*}{$\begin{array}{l}\text { Psychological } \\
\text { motives }\end{array}$} & $\begin{array}{l}\text { Less than } 10 \\
\text { years }\end{array}$ & 4.69 & 0.38 & \multirow[t]{2}{*}{1.64} & \multirow[t]{2}{*}{2.30} & \multirow[t]{2}{*}{0.055} \\
\hline & $\begin{array}{l}\text { More than } 10 \\
\text { years }\end{array}$ & 3.5 & 1.08 & & & \\
\hline \multirow[t]{2}{*}{$\begin{array}{l}\text { Economical } \\
\text { motives }\end{array}$} & $\begin{array}{l}\text { Less than } 10 \\
\text { years }\end{array}$ & 2.73 & 0.80 & \multirow[t]{2}{*}{0.06} & \multirow[t]{2}{*}{0.15} & \multirow[t]{2}{*}{0.883} \\
\hline & $\begin{array}{l}\text { More than } 10 \\
\text { years }\end{array}$ & 2.67 & 0.38 & & & \\
\hline \multirow[t]{2}{*}{ Technical motives } & $\begin{array}{l}\text { Less than } 10 \\
\text { years }\end{array}$ & 4.17 & 0.44 & \multirow[t]{2}{*}{0.46} & \multirow[t]{2}{*}{1.78} & \multirow[t]{2}{*}{0.117} \\
\hline & $\begin{array}{l}\text { More than } 10 \\
\text { years }\end{array}$ & 4.63 & 0.28 & & & \\
\hline Profession motives & $\begin{array}{l}\text { Less than } 10 \\
\text { years }\end{array}$ & 1.67 & $\mathbf{0 . 5 3}$ & 1.79 & 3.79 & 0.007 \\
\hline
\end{tabular}




\begin{tabular}{|l|l|l|l|l|l|l|}
\hline & $\begin{array}{l}\text { More than 10 } \\
\text { years }\end{array}$ & $\mathbf{0 . 8 9}$ & & & \\
\hline Total & $\begin{array}{l}\text { Less than 10 } \\
\text { years }\end{array}$ & $\begin{array}{l}\text { More than 10 } \\
\text { years }\end{array}$ & 0.31 & 0.10 & 0.48 & 0.645 \\
\cline { 1 - 5 } & 0.33 & & \\
\hline
\end{tabular}

By review the values of calculated (t), we find that it is not statistically significant because the level of significance was between $(0.15$ - 3.79), which is higher than $(0.05)$ in all the values of the calculated $(\mathrm{t})$ for all the fields and all sections of experience variable (less than 10 years/more than 10 years)

Table (11) shows the arithmetic mean, standard deviation and the calculated (t) value for fields of study depending on the profession variable

\begin{tabular}{|c|c|c|c|c|c|c|}
\hline Field & Profession & Mean & $\begin{array}{l}\text { Standard } \\
\text { Deviation }\end{array}$ & $\begin{array}{l}\text { Means } \\
\text { differences }\end{array}$ & $\begin{array}{l}\text { Calculated } \\
\text { (t) Value }\end{array}$ & $\begin{array}{l}\text { Significance } \\
\text { Level }\end{array}$ \\
\hline \multirow{2}{*}{$\begin{array}{l}\text { Verbal and } \\
\text { behavioral } \\
\text { decency } \\
\text { motives }\end{array}$} & Student & 4.52 & 0.30 & \multirow[t]{2}{*}{0.00} & \multirow[t]{2}{*}{0.00} & \multirow[t]{2}{*}{1.00} \\
\hline & Employee & 4.52 & 038 & & & \\
\hline \multirow{2}{*}{$\begin{array}{l}\text { Social } \\
\text { motives }\end{array}$} & Student & 3.00 & 0.44 & \multirow[t]{2}{*}{0.08} & \multirow[t]{2}{*}{0.28} & \multirow[t]{2}{*}{0.785} \\
\hline & Employee & 3.08 & 0.40 & & & \\
\hline \multirow{2}{*}{$\begin{array}{l}\text { Psychologica } \\
\text { I motives }\end{array}$} & Student & 3.76 & 1.54 & \multirow[t]{2}{*}{0.40} & \multirow[t]{2}{*}{0.87} & \multirow[t]{2}{*}{0.412} \\
\hline & Employee & 4.36 & 0.60 & & & \\
\hline \multirow{2}{*}{$\begin{array}{l}\text { Economical } \\
\text { motives }\end{array}$} & \begin{tabular}{|l|} 
Student \\
\end{tabular} & 2.78 & 1.07 & \multirow[t]{2}{*}{0.11} & \multirow[t]{2}{*}{0.24} & \multirow[t]{2}{*}{0.816} \\
\hline & Employee & 2.67 & 0.37 & & & \\
\hline \multirow{2}{*}{$\begin{array}{l}\text { Technical } \\
\text { motives }\end{array}$} & Student & 4.22 & 0.19 & \multirow[t]{2}{*}{0.22} & \multirow[t]{2}{*}{0.70} & \multirow[t]{2}{*}{0.503} \\
\hline & Employee & 4.44 & 0.51 & & & \\
\hline \multirow{2}{*}{$\begin{array}{l}\text { Profession } \\
\text { motives }\end{array}$} & Student & 2.00 & 1.00 & \multirow[t]{2}{*}{0.69} & \multirow[t]{2}{*}{0.83} & \multirow[t]{2}{*}{0.430} \\
\hline & Employee & 2.69 & 1.24 & & & \\
\hline \multirow[t]{2}{*}{ Total } & Student & 3.38 & 0.29 & \multirow[t]{2}{*}{0.25} & \multirow[t]{2}{*}{1.17} & \multirow[t]{2}{*}{0.277} \\
\hline & Employee & 3.63 & 0.30 & & & \\
\hline
\end{tabular}

By review the values of calculated (v), we find that the motives of behavioral and verbal decency were statistically significant because the level of significance was $(0.00)$ and is less than (0.05) and for the benefit of staff. While the rest of the values of calculated ( $t$ ) for the rest of the areas they were not statistically significant, because the values associated with the significance level were higher than (0.05), and for all sections of the profession variable (student / employee). 


\section{Results Discussion}

1. Table (2) shows the mean, standard deviation and relative importance of each item of the field of verbal and behavioral decency $(n=9)$ ]By review the values shown in the table, we find that the first item "to maintain verbal and behavioral decency ", the third, "because it offers me the freedom of movement," and seven "because it is consistent with my personal abilities "have occupied first place among the items of the field with a mean of $(5.0 \pm 0)$ and the relative importance of $100.0 \%$, this ratio is very high, which suggests a strong motivation in the physically disabled for the exercise of political participation . the researcher attribute this result to that political participation is based on a mixture of the elements of behavior and verbal decency, and thus there is a need for speech and behavior skills, while the item "because they contribute to my socialization " was ranked last because it express a clear and logical result, that the exercise of any political activity contributes to the improved decency of the physically disabled individuals in particular who want to practice politically.

2. Table (3) shows the arithmetic mean, standard deviation and relative importance of each item of the field of social motivation $(n=9)$ and by review of the values contained in the table, we find that the fourth item, which states that "because I found encouragement from my family and relatives" was ranked first. This result shows that there is acceptance and encouragement from parents and relatives for political participation by the physically disabled and this result also indicates the development of social concepts related to political participation for the disabled in general and the physically disabled in particular. While the item "to improve my financial and social status " was ranked last, and the researcher sees in this result a clear signal that there is an implicit understanding from the physically disabled that the exercise of political activity and political participation may be for purposes other than social ones.

3. Table (4) shows the mean, standard deviation and relative importance of each of the items in the field of psychological motivation where the results showed that the exercise of political activity and political participation calls for all people with or without disabilities to break the barrier of fear they have, and to rely on themselves, since this highlights the personality of the physically disabled as an individual within an informed and mature community, affects and is affected and has a contribution to the achievement if this individual distinctive, and this is only possible if the disabled are able to rely on himself and overcome the effects and psychological factors that lie ahead.

4. Table (5) the mean, standard deviation and relative importance of each of the items in the field of economic motives where the results showed that the exercise of political activity and political participation not financially or materially costly, as the researcher finds that the requirements of this practice simple and any person whether normal or disabled, poor or rich can provide them. As for the item which states "because they earn me money "and which occupied the last place: this is a natural result of non-interest of parties related to this category of society in a way that presents them as active members in the political field.

5. Table (6) shows the mean, standard deviation and relative importance of each of the items 
in the field of technical motives as the researcher attributed that the item "to raise the name of my country high in the international political forums " and "to have the opportunity to interact with my counterparts politicians abroad," were ranked the first for the feeling that physically disabled people felt when they were given the only chance to participate in the parliamentary elections for the year (2010) They believed they could offer a lot to raise the name of the country high and show their love to represent the nation abroad. While the last item "because it aims to satisfy my self-concept" indicates indifference of people with physical disabilities to aesthetic ceremonial appearances, but to participate, enjoy and achieve results and self-assertion.

6. Table (7) shows the mean, standard deviation and relative importance of each of the items in the field of profession motives where the item that was ranked first and states that "because I want to be a politically prominent in the future" is explained by that some of the physically disabled persons may see a professional "breath out" through participation in the parliament as nation representative because it is a profession with a popular and self proving personality, while the last item which states that "to gain the satisfaction and appreciation of boss at work," is explained by the researcher that there is a connection between the process of political participation and matters of personal or family, but there should be a separation between work and personal matters.

7. Table (8) Sorts the fields of study according to relative importance and it is clear that the motives of decency has ranked first rating (90.4\%) and the researcher explains this conclusion on the basis that aspects of decency required in political participation and political activity are high as they contain a combination of behavior, verbal and motor skills. Also it is a must to posses and master the elements associated with political participation for the disabled person to succeed. As for the fields of profession and economic motivation, it does not benefit now through the exercise of political participation as it is an activity that is not interested in by specialists and there is no support in any way on the professional level.

8. Tables (9) (10) (11) show the values of means, standard deviation and the value of calculated $(t)$ for fields of study according to the variables of age, experience and profession, and by reviewing the values of calculated $(\mathrm{t})$, we find that the motives of decent behavior and for the variable of profession were the only statistically significant because the level of significance was (0.00) and is less than (0.05) and for the benefit of the physically disabled. While the rest of the values of calculated $(t)$ for the rest of the variables and all fields of study were statistically insignificant, and the researcher attributes this to the small size of the study sample.

\section{Conclusions}

In light of the discussion of the results of the study the researcher was able to reach the following conclusions: -

1- the order of the motives for political participation to the physically disabled in Jordan are: verbal and behavioral decency, followed by technical motives, then psychological motives, then social motives, then economic motives, and finally the profession motives 


\section{Macrothink}

Journal of Sociological Research

ISSN 1948-5468

2012, Vol. 3, No. 2

2- The variables of experience, age, educational qualification and occupation don't have any clear effect on the variation of the physically disabled people motivation in political participation in Jordan.

3- The Motives for political participation of the physically disabled people in Jordan are positive.

4- There is a Lack of material and moral support for the physically disabled people in their political and social activities.

5- There is a Neglecting aspect of marketing and media for the political, social and cultural activity by specialists in the affairs of people with disability, especially the Supreme Council for the care of people with disabilities.

6- There is a Lack of training and educational courses, specialized activities and political participation related to this category.

\section{References}

1 - Nachoati, Abdul-Majid, (1996), Educational Psychology, Yarmouk University, Dar Al-Furqan, Jordan.

2 - Makki, Tharwat, (2005), media and politics - and the means of communication and political participation, Edition 1, Alam AL Kutub, Cairo.

3 - Baz, Dawood, (2003), the right to participate in political life, Edition 1, Dar Al Fikr AL Jami'i, Cairo.

4 - Nahed Ramzy (1991): public opinion and political psychology, Cairo, Egyptian Library of Anglo.

5 - Azzam, Abd al-Majid (2008) Trends partisan and non-partisan about government performance, and parliamentary and media in Jordan: (a comparative prospective study), Majalat Al Manar, Volume 14, number 2

6 - Al-Hazzaima, Mohammed Awad, (2005), "recognition of Jordanian voters of the factors that determine their vote," Journal of Social Sciences (Kuwait), Volume 33, Issue 3, pp. 676-710.

7 - Rabea, Amr Hashim, (1999), "The Role of Parliament in the process of democratization in the Arab countries", a paper presented to a symposium of democratization in the Arab region during the nineties, organized by the Institute of the House of Wisdom, University of $\mathrm{Al}$ al-Bayt 0.22 to 23 August, p 17, Mafraq.

8 - Naqshbandi, Baria', (2001), the political participation of women in Jordan and some Arab countries, Arab Institution for Studies and Publishing, Beirut, the first edition

9 - Mekdad, Mohamed Ahmed, (2004), women and political participation in Jordan (analytical study in the light of the results of the parliamentary elections of 2003, Al Manara Journal, Al al-Bayt University, Mafraq, Jordan

10 - Sayed, Aziza Mohamed, (1994), political behavior: theory and reality, 1st edition, Dar Al Maarif, Cairo.

11 - Kandil, Amani, (2005), civil society institutions effectiveness measure and case studies, Al-Ahram Centre for Political Studies Strategy, Cairo.

12 - Aataran, Mohamed Sayed, (1991), the role of communication in the process of political 


\section{Macrothink}

Journal of Sociological Research

ISSN 1948-5468

2012, Vol. 3, No. 2

social and economic participation - An Applicative Study on two Egyptian villages, unpublished Ph.D. thesis, Faculty of Media, Cairo University.

13 - Human Rights Council, (2011), the thematic study prepared by the High Commissioner for Human Rights on participation of people with disabilities in political and public life, nineteenth edition, annual report of the Office of the United Nations High Commissioner for Human Rights, Geneva.

14 - The Jordanian Constitution, Official Newspaper, 2011.

15 - Jordanian constitution, Official Newspaper, 1/1/1952.

16 - Arman, Raed, (2010), factors affecting the pattern of political participation in Jordanian society: a field study of the Northern Badia, unpublished Master Thesis, Institute of the House of Wisdom, Al AL Bait University, Mafraq.

17 - Al-Haddad, Kamal Shaaban, (2006), a psychological study between samples of the Palestinian participants and non participants politically, unpublished Ph.D. thesis, Islamic University of Gaza.

18 - Al Shara'a, Ali Awad, (2008), women's quota in Jordan's electoral system from the perspective of women of Jordan, Yarmouk Research, Volume 7, Number 1, Irbid.

19 - Hamza, Mohammed Tariq, (1995), the psychology of political participation: a comparative study between participants and non participants politically, Unpublished MA Thesis, University of Assiut.

20 - Shaqfa, Atta, (2008), self-esteem and its relationship to political participation among the students of Al Quds Open University in Gaza, Unpublished MA Thesis, Cairo.

21 - Qaryouti, Joseph and others, (2000), Introduction to Special Education, Dar Al qalam, Dubai.

22-Todd G. Shields. (1998), the Disability Voice in American Politics: Political Participation of People with Disabilities in the 1994 Election, Journal of Disability Policy Studies, July 1998; vol. 9, 2: pp. 33 to 52. 